Journal of Teacher Education for Sustainability, vol. 20, no. 1, pp. 157-179, 2018

\title{
Education for Sustainable Development: The Choice of Pedagogical Approaches and Methods for the Implementation of Pedagogical Tasks in the Anthropocene Age
}

\author{
Jeḷena Fedosejeva, Aleksandrs Boče, Marija Romanova, and Dzintra Iliško \\ Daugavpils University, Daugavpils, Latvia \\ Oksana Ivanova \\ Riga Technical University, Riga, Latvia
}

\begin{abstract}
Sustainable education and education for sustainable development (ESD) have witnessed a deserved number of research studies in the recent years. The present article proposes a holistic research framework for the research on sustainable education and education for sustainable development in the 21st century. The article aims to choose a more holistic research perspective by avoiding a piecemeal approach in education research. Moreover, it proposes some strategically important ideas about the use of approaches and methods for sustaining the generational readiness for sustainable development. The paper proposes a general framework for pedagogy and practice for ESD research which is open, holistic, strategic, sustainable, and integrated. A broader perspective has been developed as the relation of the ecological-cultural-social environment aspects seen in a broader adaptive evolutionary sense as a condition necessary for the development of a human species and the development of these conditions in the evolutionary process. The choice of a broader perspective is proposed by relating it to an observational study on Generation $\mathrm{Z}$ that many educators, social scientists and the populations have already started recognising as one of the participants in the intergenerational process. The phenomenon of Generation $\mathrm{Z}$ is new; its features have not fully revealed in their apparent form, yet. Furthermore, the generation has not reached its maturity yet, but the development of this phenomenon is inextricably related to the issue of generational commitment, which is also related to the evolutionary development. The observational study has been carried out by involving participants from VECC Daugavpils Vocational School. The evaluation of the participants' real experience in a wider and broader framework has been used to draw strategic conclusions, which will help keep focus on the need to sustain generational readiness for sustainable development in the harmonisation of the choice of pedagogical approaches and methods.
\end{abstract}

Keywords: sustainable development, generational succession, pedagogical tasks, generation Z, choice of approaches and methods 


\section{Holistic Research Framework for Education for Sustainable Development}

The paper considers the issue of the choice of pedagogical approaches and methods in a broader perspective to highlight the topicality of education for sustainable development (ESD). Development of a broader framework will be based on the authors' pedagogical and research experience, focusing on the choice of pedagogical approaches and methods that are related to the sustainability phenomenon and transformation of education into education for sustainable development.

The issue of the choice of pedagogical approaches and methods is inherently changing and improving due to its complex nature. It is improving if one considers it in the perspective of education and its aim development, and especially if the educational aim is formulated as the promotion of evolution of consciousness in the universe (Whitehead, 1929). Formulating the educational aim in a broader perspective of open dynamic adaptive evolutionary system in pedagogy can be considered as one of the traditional characteristics of pedagogy. However, in pedagogy, there are many cases demonstrating the educational aims to be and still are very precisely formulated and measurable. The understanding of educational aims and their discourse has been deeply rooted in the development of pedagogical consciousness and the evolution of the relationship between nature and society, which is the broadest context of pedagogy that determines the breadth and depth of the educational aim in a general or specific definition.

In recent decades, a need for a holistic understanding of sustainability phenomenon has gradually arisen, evolving as a need and condition for choosing new perspectives in education. In global use, the concept of sustainable development in the perspective of social development was formulated at the end of the 20th century, highlighting the relationship and responsibility of generations, i.e., the needs of the present generation must be met without compromising the ability of future generations to meet their own needs (UN, 1987). In spite of the global and local activities launched on the implementation of the idea of sustainable development, the 21 st century claimed to be the phenomenon of the Anthropocene age, which became a reality that had to be recognised not only in science where the phenomenon had already been known (Millett, 2015; Kress \& Stine, 2017; Tønnessen et al., 2016; Reyes, 2018).

Many changes have taken place during the establishment of the Decade of Education for Sustainable Development (2000-2005); changes have also been made to the DESD (2005-20014), there is an ongoing intensive work on the implementation of the Global Action Programme (2015-2020) (GAP) and the achievement of the Sustainable Development Goals (SDGs), as well as Education 2030 is envisaged to be implemented.

Despite intensive cooperation in achieving SDGs, the overall situation in the global development trajectory has highlighted the direction of unsustainability, in which education contributes to the regeneration of unsustainable behaviour patterns (UN, 2011). This situation has already acquired the name of the Anthropocene era in recent years (Figueroa, 2017). The phenomenon of Anthropocene has gradually been revealed and has now become a phenomenon that demonstrates the unsustainable quality of the ecological, cultural and social relationship of a human being. Anthropocene conditions have become the current pre-requisites for resolving ESD, education and science development issues.

At present, in educational studies one may encounter instances, in which Anthropocene relationships and their inherent problem solving are used as a framework for 
research. This can also be identified in cases where issues of education quality research are addressed and the foundation for educational reforms and even reform cascades is elaborated. There are also studies that look for more holistic frameworks. Calls for more holistic research are becoming increasingly common. As an example, it is worth mentioning the conference "Social Innovations 2015: Pathways to Social Changes" held in Vienna, which raised the issue of the need for more holistic research in social sciences and humanities as a challenge for future European and global research, policy and practice, and it clearly articulated the need for more holistic research, again.

Mentioning some introductory ideas at the beginning of the article, we have already identified, in our opinion, the important supporting ideas that will help dip into a more holistic research framework with interest using these ideas and views in the ESD research. To our mind, the establishment of a reference system, when it comes to the development of a broader holistic framework for ESD, must necessarily begin with setting the educational aim. The formulation of educational aim with its inherent level of generalisation as well as its content indicates the approach to education and the possible search for a direction of sustainability and/or unsustainability. The formulation of the educational aim by Whitehead (1929) opens up a perspective for a holistic explanation of the evolution of both education and consciousness and proposes using a comprehensive explanation of the evolution of education and civilization. There are no restrictions in the definition; it offers a holistic perspective on the investigation of complex phenomena of education and their relationship.

In the current circumstances, Whitehead's educational philosophy plainly addresses the issue of complex, currently called wicked problems, which has been the foundation of theories elaborated by many prominent scholars and researchers in the early 20th century. At that time, the perspective of a complex approach was based on the popularity of Darwin's theory. The second half of the 20th century marked the development of the theory of wicked problems, which at the beginning of the 21st century made it possible to approach wicked problems from a new perspective, without limitations and taking into account transformations that a human being acquired in their activities, attitudes and relationships, which had developed during the solution processes of wicked problems (Adam, 2016; Bogg \& Geyer 2007; Cutanda, 2014; Hauss, 2015; Holland, 2014; Koopmans \& Stamovlasis, 2016; Salite et al., 2016). The complex approach is inseparable from a holistic approach and complementarity of this approach is now known as wickedness that has already entered studies that are looking for a more holistic or just holistic research framework in order to solve contemporary wicked problems (Lewin, 1999; Mitchell, 2009; Morin, 2008; Norman, 2011; Waldrop, 1992; Wells, 2013; Вахтеров, 1913).

Broader perspective of the framework is considered in terms of a complex approach. Complex processes are non-linear, completely unpredictable. They cannot be solved at once; the humanity is solving them continuously through diverse activities. In the case of a complex approach, the understanding of processes is explained as the development of open, adaptive evolutionary dynamic processes that manifest themselves as fluctuations of the qualitative states which may lead to changes in the quality of the system that is related to changes in the direction of development processes.

Reflecting on the above-mentioned ideas and complex phenomena, which can be manifested in different forms of commitment, we can begin "rolling up" these ideas into a ball of interconnected complex ideas that can contribute to identifying a more 
holistic research framework for ESD research. Reflecting on the ideas mentioned is based on (1) our life experience and personal research interest in the use of more holistic research frameworks for ESD research, and (2) some trends that have matured in science and manifested themselves as transcending traditional studies towards broader holistic perspectives through a deeper understanding of all interdependencies and the role and interrelation of different integration approaches in the contemporary science. The choice of ideas from the viewpoint of our experience and the choice of trends with regard to different sciences and specific fields will, at first, be proposed from a very long distance and from an outside perspective. Adhering to this viewpoint, we will not lose sight of the reality of the Anthropocene phenomenon.

From this perspective, the choice of a broader holistic perspective in the current circumstances should begin with setting the educational aim. Following Whitehead's view of the educational aims, we have already highlighted the need for educational goals that do not restrict the use of the holistic framework and the implementation of the society's targeted activities as well as do not restrict the possibility of implementing the reorientation of unsustainable activities towards achieving a common educational aim. The phenomenon of Anthropocene is a substantial reason, which indicates the impact of more narrow and specific educational goals not only on education, but also on the quality of the whole system, which was most affected and is still affected by changes in nature-human relations. Public support for the implementation of the ESD goals has increased, but the state of nature-human relations has remained under the dominant influence of anthropocentrism, egocentrism and currently apparent technocentrism. Unfortunately, they are not all influences that are known in human-nature relations.

It is important to identify these different effects from their ontological perspective when formulating and elaborating an educational aim and a broader holistic perspective. The use of such a perspective, often both in research and in the organisation of practical activities, reaches the status of the so-called "research limitations". Such cases narrow down and limit both the scope of research and the evolutionary processes of consciousness in science and researchers' approaches.

Over the past decades, ontological studies can be found both in specific traditional sciences and in specific fields of science (Pipere et al., 2015; Salite et al., 2016). The development of wicked problems and the evolution of processes without an ontological basis are serious obstacles to the study of these relations.

The call for the implementation of more holistic research is becoming increasingly convincing, for example, in the formulation of ontological addiction proposed in Niiniluoto's theory (2002), in which A is ontologically dependent on B, if A does not exist without the existence of $\mathrm{B}$. In order to determine whether $\mathrm{A}$ is independent of $\mathrm{B}$, it is necessary to determine whether A will exist in the world if B disappears, or when the ontological perspective is used in theoretical studies of the Anthropocene framework and it finds the possibility of using ecocentrism that allows taking a more holistic view to a wide variety of contemporary problems and cases (Heikkurinen et al., 2015).

In the context of Anthropocene, such issues can contribute to the clarity of the limiting effects of previous years on the illusion about progress. In order to conduct more holistic research, it is necessary to evaluate the real causes of scientific constraints for cases that created current problems and deformations in the global system of relations and attitudes, which became unsustainable. 
Holistic view is also supported by Revonsuo (2006), who highlights the issue of the origin of consciousness as a biological phenomenon and looks at this issue from an etiological perspective with the aim of investigating the causes of unhealthy phenomena. In the environmental education in the 1980s and 1990s, this was taken into account and is still taken into account in terms of the holistic approach and holistic ecology. But in studies where the holistic approach has not been used, such issues are rarely raised. Revonsuo (2006) substantiates the topicality of the issue from the evolutionary perspective of consciousness as a biological evolutionary phenomenon and his vision of the world evolution related issue, which is still unresolved in science, can provide stakeholders with the prospects for holistic research and can even propose new opportunities in the search process in order to improve the role and influence of science.

The authors have "rolled up" ideas as a way of summarising the foundation that can be used in the ESD studies as a research framework, which can help scholars to find possible solutions to the problems and consequences of Anthropocene. Whitehead's proposal that the development of educational aim content should be based on the idea of promoting the evolution of consciousness, in the current situation, is no longer just a proposal for specific and profound theoretical research, as it was treated by researchers, practitioners and policy makers in previous years. It has recently become an impetus for the search of a transdisciplinary approach, where academic and applied researchers cooperate with different stakeholders with an aim of investigating contemporary complex phenomena or processes. The specific feature of the approach is that in this case participants of the research use their specific goal framework for particular activities and study the nature of the phenomenon in order to find solutions that also require a more holistic framework. This proposal enables researchers to use the open dynamic adaptive evolutionary development perspective (Koopmans \& Stamovlasis, 2016), in which the development of ecological-evolutionary relations opens up new opportunities for using more holistic perspectives for the assessment of the effects of ontological dependencies and dynamic changes on the directions and quality states of processes.

Transcending traditional sciences to wider contexts that go beyond the interests of a particular science is no longer about "the level of gentleman's courtesy", but it can be viewed as the emergence of issues that can recognise the interest of researchers in larger analytical units (Savio, 2010), which requires a wider perspective. This can be treated as interest in a more holistic research. If this is seen by generalising various cases in the development of science over the past fifty years, there can be observed the widening of the integration range from disciplinary interest to interdisciplinary and transdisciplinary. At present, there is a growing tendency towards the development of a more holistic perspective regarding the two phenomena, for example, ecology and evolution (Hendry, 2016), nature and nurture (Call, Bearer, \& Lerner, 2004), and the transfer of the findings identified in these studies from one process to another substantially similar process becomes more apparent. For example, the experience gained from the research on hurried salmon evolution can be used to evaluate human evolution, where activities and aims were not matched with the speed required for the development or excessive use of nature (Hendry, 2016). In-depth study of this category may also lead to some innovations in education or hasty reforms of education. 


\section{Pedagogy as a Framework for a More Holistic Research}

Development of a more holistic research framework involves a certain truth that philosophical systems indicate the approaches that serve as a general framework for organising research activities and choosing the appropriate research methods. The development of methodological framework in every science plays an important role in linking the perspectives of the philosophy of science and the philosophy of a particular science. Nurture is the developed philosophy of education, but the question arises why the pedagogical philosophy was not developed. Instead of the name of pedagogical philosophy, it is often possible to come across "pedagogy and philosophy" (Farguhar \& White, 2018; Haynes \& Morris, 2012). Perhaps, it could easily be argued that the perspective of pedagogical philosophy and the relation of pedagogy to philosophy have remained in the concept of pedagogical mission (Salite, 2015). The current divergence of global development to the unsustainable direction and the orientation of education towards the reproduction of unsustainable patterns of behaviour raise the question of whether the origins of pedagogy are not traced back to the history of philosophy as a united body of science in Ancient Greece. In the context of contemporary unsustainable development, the question is whether it is not necessary to look at the fact that the science of pedagogy has been for a long time under philosophy because pedagogy is a new science. Has the long-standing relation of pedagogy to philosophy strengthened wisdom in its nature and does the nature of pedagogy therefore inherit any specific characteristics of philosophy?

Has pedagogy that is included in the content of philosophy not found the way for its own quest for the formation of a person's nurture, the purpose of nurture, the development of the society's purpose and the individual's culture and consciousness, and the relation to nurture? The pedagogical mission has retained the tendency to rise beyond what is known, achieved with the appeal to develop a person's unique ability to get to know the Good, the Beautiful and the True in the world and learn how to make these values an integral part of ourselves and the world.

From the perspective of the development of pedagogy, there is a call to see that the evolution of consciousness is a complex task, in which the goal of the pedagogical mission, when viewed from the perspective of intergenerational commitment and of generational development, must also be considered a task for the search of the direction of sustainable development.

From the ontological origin, when action pedagogy had been understood as an inseparable part of philosophy, the strategic perspective of pedagogy was developed, which challenged the participants of the pedagogical process to use wider perspectives in explaining and understanding complex processes. From its origin, pedagogy has derived from philosophy teachers and acquired an inclusive, strategic, speculative and futureoriented pedagogical consciousness and the nature of science in an open dialogue environment.

The present article addresses the issue of the choice of pedagogical approaches and methods in a broader framework that is created around the concepts of education for sustainable development, generational development and intergenerational interaction in sustainable or unsustainable direction. Such a broader perspective of the research has been used, by interrelating it to the identification of practical experience of participants that took part in the observational study. The evaluation of the participants' experience in the framework of broader general research has been performed to obtain strategic 
findings, which, by harmonising the choice of pedagogical approaches and methods in a dynamic pedagogical process, would help to maintain focus on the need for generational readiness for sustainable development.

By its very nature, such a complex task corresponds to the nature of the pedagogical mission as well as the nature of pedagogy, which offers a strategic perspective for the choice of approaches and methods. The search for a pedagogical strategic perspective from a broad general holistic perspective of the research, with the assessment of a specific participant's experience at the level of the pedagogical mission, can open up a broader view on the choice of pedagogical approaches and methods that is usually considered and addressed in the educational system by somewhat narrower interest of didactics and specific scientific disciplines, which more often is proposed to meet the needs of the market.

\section{Characteristics of Generation Z}

Many educators, social scientists and the public have already started recognising Generation $\mathrm{Z}$ as one of the participants in the intergenerational process. The phenomenon of Generation $\mathrm{Z}$ is new, its features have not fully revealed in their apparent form yet, the generation has not reached maturity yet, but the development of this phenomenon is inextricably related to the issue of generational commitment, which already now has the sense of the evolutionary development, and it was both in the development process of the human species and long before the development of the human species as the first beginning.

Therefore, we have constructed our perception of Generation $Z$ by studying opinions of practitioners and researchers about the features of Generation $Z$ that have already been identified in different sources. We have found out that scholars have drawn attention to the issue of Generation $Z$ due to a variety of reasons (accidental interest, concerns about the development trends of society, worries about the health of Generation $\mathrm{Z}$ and the further development of this issue, the attempt to understand the generation as a whole, the development of the Generational Theory, etc.). We have investigated the already known features and evaluated them from the perspective developed as our view of a more holistic research framework for ESD. In this holistic framework, we have included the framework of pedagogy in its broadest sense.

In this framework, we have also included known and more specific features and trends of Generation $\mathrm{Z}$ as well as identified the issues that arise in the perspective of a more holistic framework, which is much broader as it is needed for the analysis of specific characteristics. A broader framework to our issues opened up the opportunity of supplementing analytical and evaluative thinking with the integration, synthesis and synergy contexts by constructing perception of Generation Z. In the context of our research, these issues are of value if we consider value from the perspective of the desired outcomes and research framework allows searching for these desired outcomes in the direction of enhancing sustainability, integration, analysis and content items, in the compliance of adaptation and evolutionary process with time requirements necessary for continuity conservation in education and sustainable development processes. Using a broader and more holistic framework, we can relate the known with issues that are not evident at a particular research level, which allows observing specific characteristics and properties only as complex formation, limiting the possibility of viewing the formation 
as belonging to a wider complex phenomenon and in conjunction with other complex phenomena in the complex world. This opportunity is opened up by the specific nature of pedagogy, which gained its nature evolving within the philosophical framework, and which today is as ontological origin of pedagogical science.

By surveying the sources of literature on Generation Z, we have found several features that indicate trends in the studies of Generation Z, which enabled us to identify issues that are valuable in the context of education for sustainable development. The present article will focus on the four trends that already provide a basis for more holistic research in education: (1) the development and improvement of the Generational Theory; (2) the relation of Generation $Z$ to the technological environment; (3) social experience of Generation Z and environmental impact; and (4) activity, cooperation and mind-set trends of Generation Z.

\section{Development and Improvement of the Generational Theory}

Neil Howe and William Strauss proposed the Generational Theory, stating that generation is determined not only by the birth years but also by the values that result from their experience (Howe \& Strauss, 2009). Values work invisibly and determine our behaviour in many aspects of life: the way we communicate, manage conflicts, and the factors that motivate us.

It is now apparent that in the studies on Generation $\mathrm{Z}$ scholars are searching for answers to the development of generation and its period of existence. It is mentioned that Generation Z was born around 2000 (Сапа, 2014), American researchers state that Generation $Z$ was born in the period of 1993-2005 (Turner, 2015), Lithuanian researchers also support the view that the generation period is from the late 1990s to the early 2000s (Levickaite, 2010), and Latvian researchers (Jurgena et al., 2018) consider that the development of Generation $\mathrm{Z}$ is related to the effects of global unsustainability and technology, and focus on a weak degree of integration of natural sciences and social sciences.

Generation Z already has a number of "working” titles found in research (Generation Z, Generation M, Net Generation, Internet Generation), which demonstrate the tendency that the issue of Generation $\mathrm{Z}$ is viewed as a transition generation developed between the 20th century and the 21 st century. The development of the Generational Theory enables us to see its specific nature and the way, in which the generation fulfils its activities in the environment inherited from previous generations and changed as a result of its activities.

In the context of our research, we have concluded that a more holistic development of the Generational Theory is one of the opportunities for solving the existing educational problems and reorienting education to sustainable development. The development of the Generational Theory is one of the issues that opens up an opportunity for the development of more holistic research as well as provides the ability to seek and find approaches and methods for overcoming the limitations of research that can enter education and science through natural changes in human-environment relations and which may also occur in education and science due to non-compliance of approaches and methods, which can lead to hurried or delayed processes. At the beginning of the paper, we have already related it to the development of the Anthropocene phenomenon. From the perspective of our more holistic framework developed, where pedagogy has been viewed from its broader, initial and ontologically determined perspective, it can be 
seen that the development of the Generational Theory should be further developed on the basis of a complex approach, which provides an opportunity to conduct more holistic research in education. In terms of the Generational Theory, the concept of generation is a broader research unit, which refers to respect for the species evolutionary process, in which there is the indivisible relation of each individual as the human species and a member of society to the environment. It is a unit of quality of these relations, which also determines the quality of the entire system.

\section{Relation of Generation $\mathrm{Z}$ to the Technological Environment}

Studies of Generation $Z$ share a common feature; they relate to the use of technology. The studies address issues related to the search for new methods, the provision of new information and the ways of its distribution affecting all aspects of life and changing the educational environment. New complex problems arise that become trends when everything is mixed up and can be introduced as a broader category by referring to it as intermingle (Salite, 2015) or other phenomena occur that affect the educational environment and develop the e-learning environment (Kapenieks, 2016; Kapenieks \& Salite, 2012).

What was considered the "future technology" for the previous generation became reality for Generation Z. Generation $\mathrm{Z}$ is an active user of technology and sees the technology as an instrument (Van den Bergh \& Behrer, 2016). Generation Z presents a challenge to society as many people think that their behaviour is quite different, in particular different from previous generations, and this behaviour can lead to changes in consumer behaviour (Schlossberg, 2016). But, at the same time, the perception is developing and experience is accumulated that work with the cutting-edge technology promotes a more professional activity, which also contributes to the sustainable development of one's own life and the environment.

From a broader perspective and in particular from the ontological perspective, technology has been and also remained an instrument or a tool. In the context of action process and work, its essence has not changed. The aims of its use have not also changed since all Homo sapiens used tools of previous generations as instruments that were consistent with the consciousness that man had attained at that time and served as the search for new tools and the further evolution of consciousness.

In the context of the Anthropocene era, thinking and action have changed and there one can identify a lack of succession and interrelation. In the first part of the paper, we have referred to Niiniluoto's (2002) foundation of the ontological addiction. In the Anthropocene, we can ask a question whether anthropocentrism will exist with the technosphere if the ecosphere disappears. And will it be possible to save education from unsustainability if the deepest ontological roots of pedagogy that are no longer in the science of education are destroyed?

\section{Social Experience of Generation $\mathrm{Z}$ and Environmental Impact}

Emily Anatole emphasises that Generation $\mathrm{Z}$ is realistic and pragmatic. Generation $Z$ was born seeing terrorist acts, surviving crises, seeing their parents overcome challenges in life (Anatole, 2013). Generation Z lives in an era of economic and political instability, tough competition and globalisation, and especially this generation needs to take action so that life on the Earth could continue. 
Today's young people living in the technology age are different, and this is selfexplanatory. But in generational research for ESD, one has to look for the answer: what are the changes in terms of the quality and development direction of the generation's life-sustaining activity? Will these changes contribute to the progress of the society towards sustainability, or sustain unsustainable Anthropocene relations? The variety of theories, known fragmentation, mixing everything and hybridization are the conditions of the Anthropocene age; it is the environment of living conditions of Generation Z. In these circumstances, education does not look for Aristotle's educational tasks, where Aristotle envisaged the development of knowledge, skills and phronesis (practical wisdom) (Aristotelis 1985; Salīte, Gedžūne, \& Gedžūne, 2009). The endless education reforms or even cascades of reforms are a characteristic feature of Anthropocene, which has been accompanying Generation $\mathrm{Z}$ since its inception.

There are many different theories that are internally and mutually controversial. In the sources of literature, one can find the conclusion that there is no evidence of the harmful or beneficial effects of the current circumstances on young people. The changes in the Anthropocene era have gone a long way towards unsustainable development, and the need for more holistic research in science has serious implications that suggest that in unsustainable relationships one should seek new perspectives that can help understand the ongoing fundamental changes.

\section{Activity, Cooperation and Mind-set Trends of Generation Z}

Characteristics of Generation $\mathrm{Z}$ have many contradictions that have arisen in the environment saturated with contradictory processes and their consequences. There are many different views about the readiness of Generation $Z$ to address life and inherited environmental problems. In the communication and information field, in which Generation $\mathrm{Z}$ is developed, there is pollution and all kinds of addiction, which already raise concerns about the health of the generation and the further path of consciousness evolution. Almost all information is found on the Internet by young people, they do not ask parents, teachers, the first thing they do is asking Google. They find the location with the help of a navigator, and they buy everything they need online. The skill and the habit of simultaneously doing homework, living in social networks, listening to music, and fulfilling other urgent work are the combination of activities and cooperation of Generation Z, which is a generational feature.

Perception speed is increasing. In the e-environment, everything happens much faster than in real life. Everything is perceived quickly and haste becomes apparent in the action process. The perception of the real world is distorted due to its inherent lack of perceptive experience and unnatural, over-saturated recognition due to the perception of technical information. The perception of the ecological-cultural-social environment necessary for human life is changing. In the first part of the paper, we have mentioned an example of the phenomenon of the hurried salmon evolution, which is known as a phenomenon for the pursuit of human hasty interests. By analogy, we can ask the question: are there any similarities in education reforms with this mankind's experience of spurring development? The current environment and the activity, cooperation and mind habits of Generation Z, which become recognisable, are the reason for seeking answers to these questions in the educational research for ESD.

The impact of the technology has led to the fact that young people do not need to remember everything because information can be found quickly. At the same time, it is 
believed that Generation $\mathrm{Z}$ analyses a large amount of information without problems and can quickly find the answers they need.

In the context of our more holistic research framework, the question arises: at what level is this analysis implemented? Does the analysis relate to the mind and activity habits of synthesis, integration or synergistic competence? The need to develop research in this direction is reassured by a number of features that have become characteristics of Generation Z:

- The brain is accustomed to fast perception of information, boredom appears at a less intense flow of information;

- Life must be dynamic; movement, emotions and spontaneity are needed;

- Text message thinking, difficulties in expressing thoughts in live conversation;

- Clip thinking, difficulty concentrating on the studied subjects during one and a half hours, the need to use a variety of methods aimed at drawing and sustaining attention;

- Multimedia technologies are being used inefficiently.

Employers have observed that Generation $\mathrm{Z}$ is convinced that they are invincible; they show desire for "big money", desire not to be involved in the work process and weak interest in work.

Generation Z has a different mind-set with a different perception of the world. The influence of the Anthropocene on its activities, cooperation and mind habits is already evident, and this is a condition that requires the society to address the issue of conducting more holistic research and implementing education reforms.

\section{Methodological and Theoretical Assumptions of the Observational Research}

Global changes in society have significantly changed the social habits of children and young people; they are radically different in the daily activities, the understanding of values and the life goals. Therefore, we have created a broader and more holistic perspective when developing the framework of the research, in which we responded to the pedagogical tasks, pedagogy as a broader perspective of science, revealing its broader and deeper essence: orientation towards sustainability, unifying aim, action, participation, cooperation, research, learning, strategic vision, integration, ontological addiction and value creation. We have established the theoretical foundation around the concept of generation, referring to the Generational Theory. In the research devoted to the issues of generation and the Generational Theory, there is a tendency that researchers use traditional methods, carry out experiments, refer to the result of experimental and control groups and obtain conclusions that speak precise mathematical language. But in pedagogical science, the mission of a teacher, the essence of which was found at a time when pedagogy was not separated from philosophy, speaks another language that through action invites, inspires, opens up to participation and gains experience.

The view that a student learns and develops in the process of gaining experience is supported by many Latvian scientists (Pētersons, 1931; Students, 1998; Žogla, 2001). Latvia has developed experience in which not only scientists from Latvia and the Baltic States, but also scientists from Europe and other countries in the world have been involved in educational research for ESD. Since 2007, these studies have been concentrating around the Journal of Teacher Education for Sustainability (JTES); the Journal of Discourse and Communication for Sustainable Education (DCSE) joined this process in 2010. 
The journals have already accumulated research demonstrating the goals of sustainable development, the nature of sustainable education and the phenomenon of sustainability (Bell, 2016; Carbach \& Fischer, 2017; Huckle, 2012; Hurtman, Johnson, \& Hill, 2017; Kalaitzidis, 2012; Makrakis \& Kostoulas-Makrakis, 2012; Miedema \& Bertram-Troost, 2015; Pace, 2010; Tillmans, Holland, \& Filho, 2017). Apart from traditional research, JTES has accumulated experience in using participatory and / or educational action research in more holistic research (Gedžūne \& Gedžūne, 2010; Grišāne, 2008; Pipere \& Salite, 2006; Salìte, 1998; Salìte, 2008; Soobik, 2014), and there are also studies and experiences that seek to underpin the use of approaches and methods in the current context (Aldahmash et al., 2017; Flores et al., 2014; Hurtman et al., 2017; Kabadayi, 2016; Mohammadi \& Moradi, 2017; Okeke \& Mtyuda, 2017; Zunker, 2012). These studies recognise the distinction between a sophisticated and complex approach, and provide the opportunity of using a more holistic research framework. Salumaa believes that all organisational and technical difficulties that arise in the action process can be successfully solved, unless people take active part in it (Salumaa, 2017).

In terms of the research methodology for conducting a more holistic research, the authors have chosen the framework of the educational action approach, which opens up the opportunity for organising a more holistic action, which allows the action to be carried out around the interests of the participants themselves, to work around matters that are important to their lives. Especially since the action research has a strategic potential and serves also as a method for organising and implementing the action (Kapenieks \& Salìte, 2012; Kravale-Paulina \& Oḷehnoviča, 2015; Salìte et al., 2016). We have been convinced of this choice by the specific features of Generation $Z$ that have already become apparent in observation (the basic method of pedagogy) and investigation of participants' experience and results obtained in action using qualitative methods, which are natural to the methodology of the action research and are in good agreement with the holistic nature of pedagogy and the cyclical nature and growth of the action research that are identified by the participants themselves as changes gained.

The choice of the research foundation has also been based on the relationship between pedagogy and philosophy, as seen by Dewey, which was his fundamental faith in pedagogy, which he linked to the Melioristic Motive, or the faith that this life was neither perfect nor bad that it could be improved only through human effort (Hildebrand, 2008).

If adults and researchers who study youth culture find it different, unknown and incomprehensible, more holistic research should enable young people to address their own life issues in the way they see it and help them find the most important educational aim.

The research on this topic is of interest to business executives, education system representatives and those who need to get along with young people on a daily basis. Therefore, the issue is open for discussion and there is a reason to consider a variety of typical features of Generation Z.

\section{Aims, Tasks and Course of Implementation of the Educational Action Research}

The educational action research was initiated pursuing the significant aim for the development of an educational institution, to improve the study programmes by developing an integrated cooperation model promoting the development of an educational institution. 
The article presents one of the cases of this broader action research, the task of which was to initiate the improvement of the study environment of the technical study course "Railway Technical Operations Regulations" by launching educational action research in order to use the cooperation force of students and instructors to improve the study environment of the study course. We call this part of study the observational research.

Improvement was initiated with the aim of enhancing the study course by:

(1) methods and techniques for identifying problems, visualisation, making personal meaning and discovering new values, integrating professional business games in the study course;

(2) pedagogical conditions such as collaboration, conflict resolution, compromise and cooperation, by undergoing transition from knowledge assessment to academic achievement assessment, organising cooperative learning during practical classes and introducing cross-curricular integration.

\section{Research Design and Participants}

The observational research involved three student groups and instructors, who were also participants in the action research. Such research has been conducted for the first time, in Latvia educational action research at vocational schools is a new approach. The observational research involved three groups of students acquiring the study course "Railway Technical Operations Regulations" at VECC Daugavpils Vocational School. A total of 67 students were surveyed: the first and second groups ( $n=23$ and $n=22$ students, respectively) and the third group ( $\mathrm{n}=22$ students). Participants were 17-18 years old. The duration of the observational research was half a year. In this research design, the authors used two variants of the intended educational action research. We anticipated that action research would be more holistic and affect participants to a larger extent, in which most participants would open up to solving important issues of their life with personal interest, and a more open cooperative environment would be created in the context of action research. The relationships in which an instructor as a participant of an action research invites students to solve real-life problems through action might be less open.

In the first variant, we involved two groups of students and organised action, allowing the participants of the research themselves to look for opportunities to address the issues of improving the study environment within the study course. In this type of the action research, instructors listened to the students' proposals and supported the students' ideas and choice of action, or instructors followed the students' ideas and engaged in their implementation.

In the second case, in the third group, the implementation of the educational research was organised on the basis of an instructor's leading role well recognised in education and the involvement of students in the action, following the ideas proposed by the instructor, persuading students that this would improve their own life in the educational institution and their future professional life. The role of the instructor in both cases was understood within the framework of educational action research, which would provide opportunities for implementing a more holistic perspective. The use of an open perspective within the framework of the action research is a feature that was taken into account and interrelated to the task of improving the study environment for the acquisition of the study course. The third group preserved the relationship between the instructor and 
the students that did not destroy the perception of an instructor's leading role and did not abandon the prevailing beliefs of adults usually looking for "how should be done and should be right", as we found out this was a way that did not completely correspond to the nature of Generation Z.

By using these two cases, the authors intended to create a situation to demonstrate that an instructor's leading opinion might also have less impact in the case of action research, as it was in action research that was personally significant. Consequently, we attempted to demonstrate the importance of the strategy, methods and techniques used to investigate generational needs and habits.

Quantitative and qualitative research methods were used in the part of the observational education research. Especially an observational method characteristic of pedagogy was used. At the beginning of the study course and upon its completion, students and instructors, as well as participants and observers involved in the implementation of the study programme assessed the benefits gained in the action research, which were considered in a broader perspective of the overall aim of the educational action research, in the context of development of programmes and elaboration of an integrated cooperation model.

In the observational education research, we found out four criteria that were identified by participants in both surveys and observations throughout the course of the research and at the beginning and the end of the research. We used these indicators to visualise the changes gained during the research at the trend level.

\section{Research Findings and Conclusions}

In the paper, the authors used only the results obtained by organising and implementing the action research on (1) the need to elaborate the four cooperation criteria; (2) the gradual recognition of the content of the criteria in the complex improvement of the study environment within the study course; and (3) the ability of the research participants to evaluate the changes in their experience, which occurred during the educational research process.

The idea of improving the programmes at VECC Daugavpils Vocational School has been matured for a long period of time as a personally significant need of instructors related to their professional development activity and as an important need for institutional development promoted by the development of education policy at the global and local levels, and in particular by the institution's cooperation with various partners in terms of programme and institutional improvement.

Consequently, before the idea of an educational action research, the need to improve study courses and programmes has already been topical. At the initial stage, the action research into the study course was based on the tasks of the observational research: (1) to find out the participants' opinions about the current situation; (2) to enable participants to agree on the criteria to be used in the research (2.1) in order to identify and visualise the trajectories of change and (2.2) for conceptualising the experience gained and conclusions, to integrate the individual feelings and those gained in teamwork into the visualised trends of the trajectory direction of action research assessment and (3) to find out the participants' opinions about the situation and benefits upon the completion of the study course.

Initiating the research in the description of the situation, the participants noticed some of the essential features of the situation: 
- The study process was described as tedious, pattern-like and reproductionoriented process. Generalising various views expressed in the surveys, interviews and discussions, the characteristics mentioned by the participants were within the framework of the present unsustainable education;

- In the opinions expressed by the students, their interests were mainly related to the belonging to the peer group, the problems of out-of-school life (family, financial, dormitories, etc.) followed by the need for professional development;

- The interest in professional development revealed that in students' interest there was room for peculiar either, or where it appeared that students experienced a lack of either fundamental knowledge or the skills to use the acquired knowledge in problem solving.

At the beginning of the research, the participants examined their experiences and beliefs, and set up criteria that, in their opinion, could be used to identify the phenomenon of cooperation. Four criteria for recognising the phenomenon of cooperation were distinguished:

- Teamwork, observed by recognising the cooperation commitment, which was manifested as the team unity to a greater or lesser degree;

- Cooperative learning, recognised by the participants in terms of the visible features of the action process of experience and knowledge exchange, especially after engagement in solving problems arising from learning activities;

- Business communication, recognised by features of individual responsibility for particular assignments and responsibility for assigning the team roles, which demonstrated an apparent change in the perception of the organisation of a professional railway transport process;

- Creative activity, recognised by the ability to find innovative and original solutions based on the combination of existing experience and knowledge for the individual and the group in the attained perspective of the perception of the world, the concentration of action and thinking habits on the issue that challenges the ability to integrate experience, knowledge, action habits by concentrating one's own ability and opportunity (individual and team) to synthesise creative solutions in the holistic perspective thus obtained.

At the end of the observational action research or upon the completion of the study course:

- The participants evaluated the most useful skills, knowledge and the change in the cooperation skills, where the dominant skills were the ability to read and draw drawings - electrical circuits, maintain locking devices, plan different routes, place and transfer consignment, make financial calculations, comply with the occupational safety, electrical safety and fire safety regulations;

- The participants also identified the knowledge and skills that seemed necessary in the future professional activity, but they lacked them during the acquisition of the study course, e.g., the ability to fill in technical documentation, perform maintenance of equipment and serve electrical equipment stations etc., which indicated students' interest in acquiring practical skills.

The research design provided the characteristics of the three groups of participants who acquired the study course "Railway Technical Operations Regulations" and, within the educational action research, cooperated to investigate the opportunities for improvement of the study environment within the study course. 
In the two groups, all participants had the opportunity to work with the interest that they sought within themselves and developed in cooperation. The third group was offered a variant where the proposals to engage in the action research and to solve important issues of their life were made by the instructor and through them the students formed their opinion on using the content of the action research and cooperation opportunities.

At the beginning of the research, for the developed cooperation phenomenon recognition criteria used by the participants of the three groups, four criteria were applied, to which the levels of manifestation recognisable in the cooperation process were allocated: (0) did not participate, (1) participated partly, (2) participated with interest, (3) fully engaged in the process.

We used the cooperation phenomenon recognition criteria to visualise the recognition of this phenomenon at the beginning and the end of the research, when the acquisition of the study course was completed. Figures below provide the opportunity to observe trends in the range from non-involvement to full involvement in the process, which were identified at the beginning and the end of the research.

Group 1

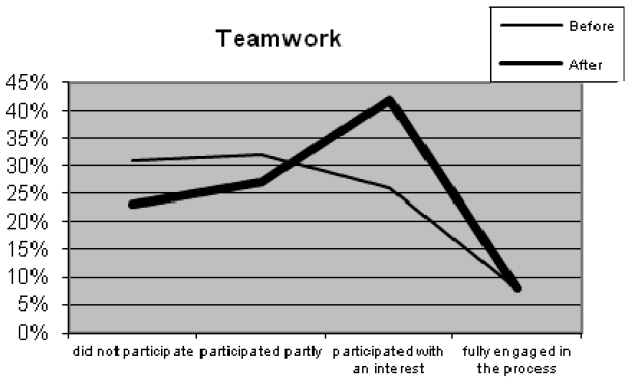

Fig. 1. Teamwork

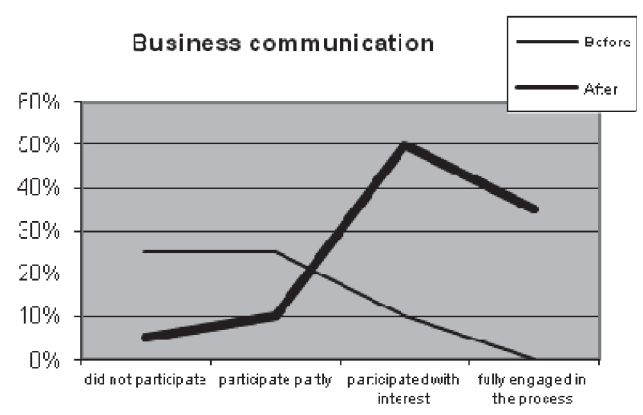

Fig. 3. Business communication

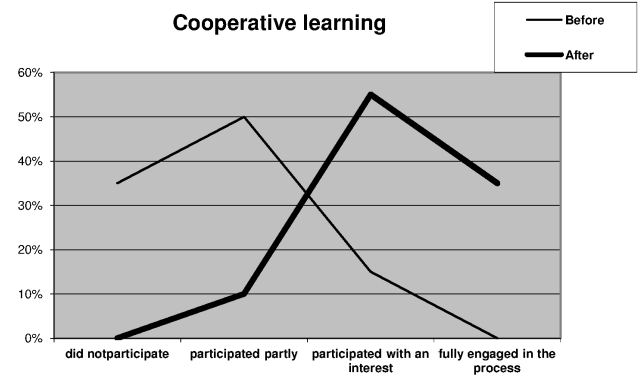

Fig. 2. Cooperative learning

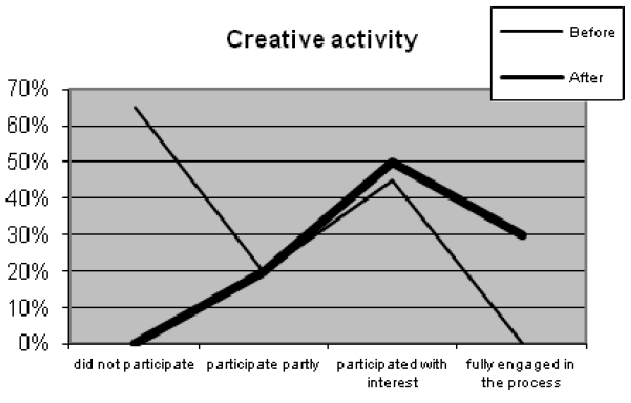

Fig. 4. Creative activity

In the present educational action research, trends were obtained in each of the groups involved in the research. In Group $1(n=23)$, at the beginning of the research in terms of teamwork (Fig. 1) there was non-engagement and partial involvement of participants observed and at the end of the research growing interest and partial involvement of participants was identified; in terms of cooperative learning (Fig. 2) partial cooperation and non-engagement predominated at the beginning of the research, and at the end of the research there was a tendency to act on the basis of interest and full 
involvement. In terms of business communication (Fig. 3), at the beginning of the research, there were non-engagement and partial involvement and at the end of research interest and full involvement observed; and in terms of creative activity (Fig. 4) at the beginning of the research there were non-engagement and partial involvement, and interest and full involvement - at the end of the research.

\section{Group 2}

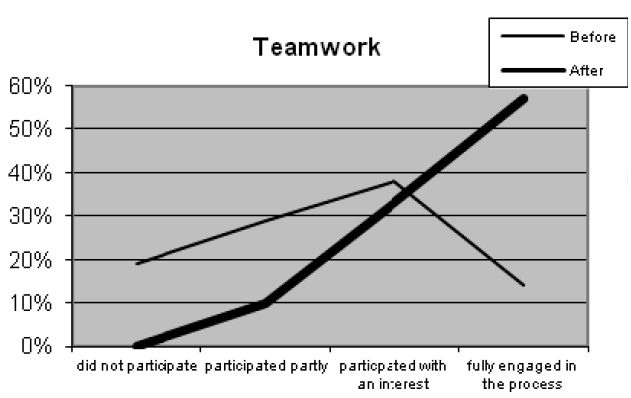

Fig. 5. Teamwork

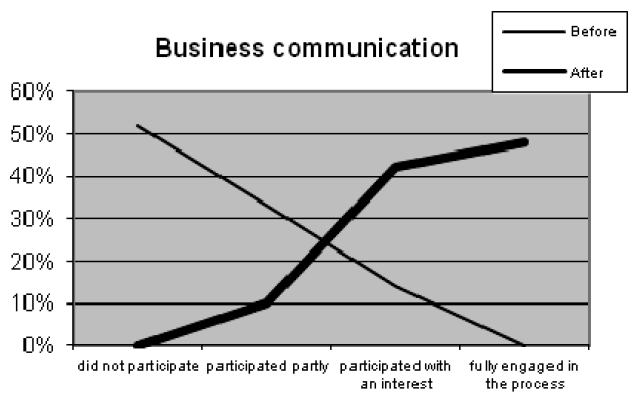

Fig. 7. Business communication

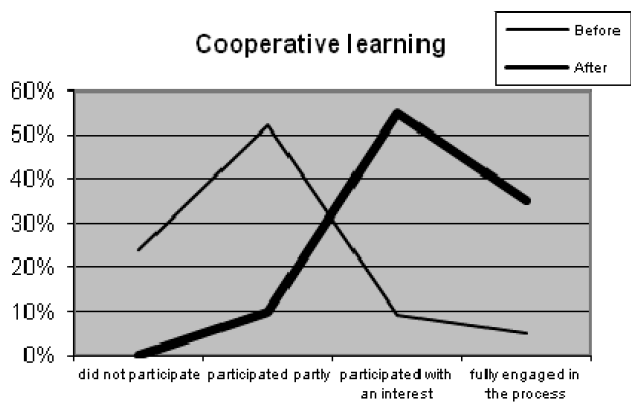

Fig. 6. Cooperative learning

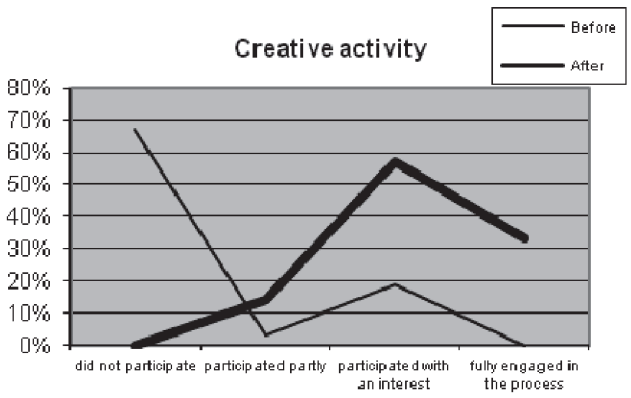

Fig. 8. Creative activity

In Group 2 ( $\mathrm{n}=22$ ), at the beginning of the research, in terms of teamwork (Fig. 5) interest was dominant and full involvement was observed at the end of the research; in terms of cooperative learning (Fig. 6) at the beginning of the research partial engagement was more characteristic and at the end of the research interest and full engagement were observed; in terms of business communication (Fig. 7) at the beginning of the research non-engagement was observed and full involvement with interest in the action was dominant at the end of the research; in terms of creative activity (Fig. 8) at the beginning of the research there was a tendency not to participate, and at the end of the research there was a tendency to engage with interest and fully participate.

In Group 3 (n=22), in terms of teamwork (Fig. 9) at the beginning of the research engagement with interest was dominant, and at the end of the research there was a slightly greater tendency not to engage or partially engage; in terms of cooperative learning (Fig. 10) both at the beginning and the end of the research there was a tendency to partially engage; in terms of business communication (Fig. 11) at the beginning and the end of the research there was a tendency not to engage; and in terms of creative activity (Fig. 12) both at the beginning and the end of the research there was a dominant tendency not to engage. 
Group 3

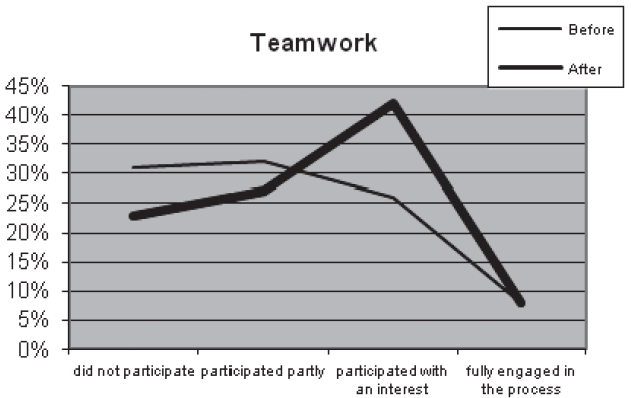

Fig. 9. Teamwork

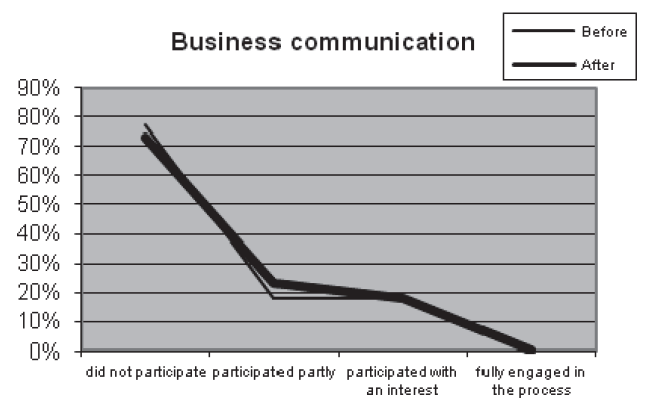

Fig. 11. Business communication

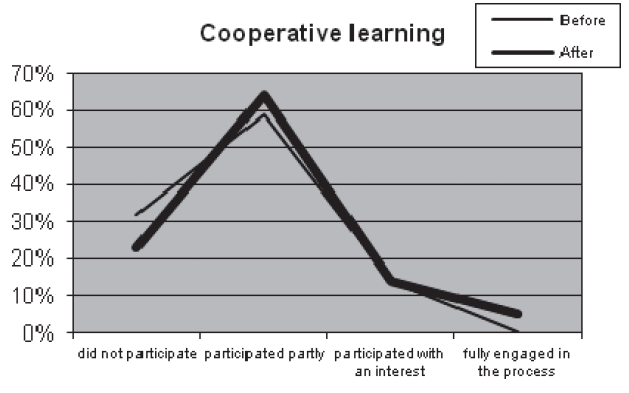

Fig. 10. Cooperative learning

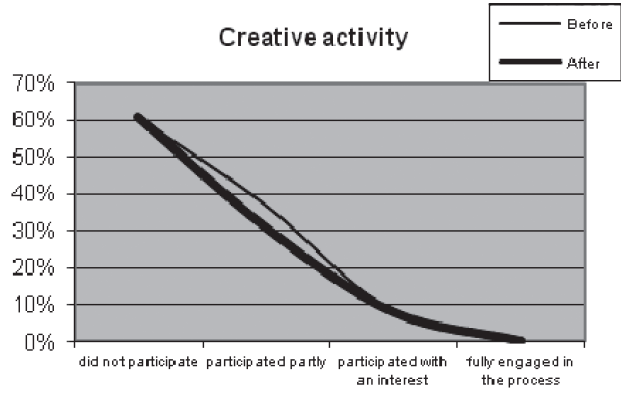

Fig. 12. Creative activity

The following conclusions on the findings of the research trends have been made by generalising the obtained data based on a qualitative assessment method:

- According to the teamwork criterion, at the beginning of the research process the activity of Group 1 was more based on partial participation, but at the end of the research they were acting on an interest basis. At the beginning of the research, Group 2 was relying on interest rather than engagement in teamwork, but at the end of the research, they acknowledged that there was a real engagement in the teamwork. At the beginning and the end of the research, Group 3 either partially engaged in the teamwork or did not engage at all.

- According to the cooperative learning criterion, it can be observed that the participation of Group 1 in the action research was based on partial involvement and non-engagement, at the end of the research it was based on interest and full involvement; at the beginning of the research the participation of Group 2 was based on partial involvement and non-engagement, but at the end of the research they recognised that they acted on the basis of interest and full involvement. At the beginning and the end of the research, the activity of Group 3 was based on partial involvement or non-engagement in the cooperative learning process.

- By generalising the data on business communication criterion, it became apparent that Group 1 was partially involved or did not participate in the process at the beginning of the research, but at the end of the research they demonstrated partial involvement or interest. At the beginning of the research, 
Group 2 engaged with interest or did not engage at all, but at the end of the research they worked on the basis of partial involvement or interest. At the beginning and the end of the research, Group 3 demonstrated non-engagement or partial involvement.

- By generalising the data on the creative activity criterion, it was observed that at the beginning of the research Group 1 participated based on interest and non-engagement, but at the end of the research, they acted on the basis of interest and full involvement. At the beginning of the research, the activity of Group 2 was based on non-engagement and interest, but at the end of the research it was recognised that the activity was carried out with interest and full involvement. The results of Group 3 demonstrated that at the beginning and the end of the research, creative activity was based on the involvement and partial involvement of participants.

The involvement of Group 3 in the educational action research demonstrated that the data of all four cooperation criteria indicated the tendency for participants' engagement to be based on partial involvement or non-involvement. This is evident in all the criteria as the fluctuations between these two forms of partial involvement or noninvolvement and within the research in Group 3, in just a few cases, the participants' activity was based on the interest in participating in a joint action.

The research demonstrated the tendency for an activity in an educational action research to be organised in such a way as to enable participants to find the basis of their involvement, by associating it with their life deep-seated issues and their interest in acquiring the study course.

The trends observed in the research indicate that the organisation of activities in Groups 1 and 2 was based on a more holistic approach and it had more opportunities to rely on the participants' personal involvement and full involvement in the educational process. A more holistic educational action research opens up the opportunity of wider use of methods that affect deeper engagement, and the choice of these methods comes from participants as a demand for more dynamic methods related to deeper engagement.

\section{Conclusions}

The theoretical foundation of the research highlights the topicality of education for sustainable development. Development of a broader framework is based on the authors' pedagogical and research experience, focusing on the choice of pedagogical approaches and methods that are related to the sustainability phenomenon and transformation of education into education for sustainable development.

A holistic understanding of sustainability phenomenon in the article is reflected as a need and condition for choosing new perspectives in education. Broader perspective of the framework is considered in terms of a complex approach that is non-linear and completely unpredictable.

The development of a broader framework calls for the evolution of consciousness as a complex task, in which the goal of the pedagogical mission is viewed from the perspective of intergenerational commitment and of generational development, and considered as a search of the direction of sustainable development. The present article addresses the issue of the choice of pedagogical approaches and methods in a broader framework that is created around the concepts of education for sustainable development, 
generational development and intergenerational interaction in sustainable or unsustainable direction.

The focus of the research has been the today's Generation Z that lives in the technology age and is represented by completely different people with a completely different mindset and different perception of the world compared to the previous generations, which calls for a completely different organisation of the study environment and requires developing more creativity, autonomy and critical thinking in the culture that is different, unknown and incomprehensible.

\section{Acknowledgement}

The authors of the article would like to express their greatest acknowledgement to professor Ilga Salite for her mentoring, support and inspiring while conducting this research. A special gratitude we give to our professor Ilga Salite for stimulating suggestions and coordination of this research project as well as in guiding the team in achieving the goal. Furthermore, we would also like to acknowledge Hussein Meihami with much appreciation for helping with the language issues.

\section{References}

Adam, R. J. (2016). Education for wicked problems and the reconciliation of opposites: A theory of bi-relational development. Abingdon: Routledge.

Anatole, E. (2013). Generation Z: Rebels with a cause. Forbes, Retrieved June 14, 2018 from https://www.forbes.com/consent/?toURL=https:/www.forbes.com/sites/ onmarketing/2013/05/28/generation-z-rebels-with-a-cause/.

Aristotelis. (1985). Nikomaha ètika [Nicomachean ethics]. Rìga: Zvaigzne.

Bell, D. V. J. (2016). Twenty-first century education: transformative education for sustainability and responsible citizenship. Journal of Teacher Education for Sustainability, 18(1), 48-56.

Bogg, J., \& Geyer, R. (2007). Complexity, science and society. Abingdon: Radcliffe Publishing Ltd.

Carbach, E., \& Fischer, D. (2017). Sustainability reporting at schools: challenges and benefits. Journal of Teacher Education for Sustainability, 19(1), 69-81.

Cutanda, G.-A. (2014). Analysis of Mythical-Metaphorical Narratives as a Resource for Education in the Principles and Values of Sustainability. Journal of Teacher Education for Sustainability, 16(2), 18-38.

Decade of Education for Sustainable Development (2000-2005). (n.d.) Retrieved from http://unesdoc.unesco.org/images/0014/001416/141629e.pdf

Figueroa, A. (2017). Economics of the Anthropocene age. Retrieved June 14, 2018 from https://books.google.lv/books? isbn=3319625845

Flores, M. A., Santos P., Fernandes, S., \& Pereira, D. (2014). Pre-service Teachers' Views of Their Training: Key Issues to Sustain Quality Teacher Education. Journal of Teacher Education for Sustainability, 16(2), 39-53.

Gedžūne, G., \& Gedžūne, I. (2010). Social exclusion in education: pre-service teachers' perspective. Journal of Teacher Education for Sustainability, 12 (1), 85-99.

Global Action Programme (2015-2020). (n.d.) Retrieved from http://unesdoc.unesco.org/ images/0024/002462/246270e.pdf 
Grišāne, O. (2008). Designing environment for research and learning in secondary school. Journal of Teacher Education for Sustainability, 10, 17-31.

Hauss, C. (2015). Security. 2.0: Dealing with global wicked problems. New York: Rowman \& Littlefield.

Haynes, J., \& Murris, K. (2012). Picturebooks, pedagogy, and philosophy. London: Routledge.

Heikkurinen, P., Rinkinen, J., Jārvensivu, T., Wilen, K., \& Ruuska, T. (2015). Organising in the Anthrocene: An ontological outline for ecocentric theorising. Journal of Cleaner Production, 1- 10.

Hendry, A. P. (2017). Eco-evolutionary Dynamics. Princeton and Oxford: Princeton University Press.

Hildebrand, D. L. (2008). Dewey: A Beginner's Guide. Oxford: Oneworld.

Holland, H. H. (2014). Complexity. A very short introduction. Oxford: Oxford University press.

Howe, N., \& Strauss, W. (2009). Millennials rising: The next great generation. New York: Knopf Doubleday Publishing Group.

Huckle, J. (2012). Teacher education for sustainability in network society: combining digital and sustainability literacies. Journal of Teacher Education for Sustainability, 14(2), 41-53.

Hurtman, R. J., Johnson, E., \& Hill, M. (2017). Empathetic design: A sustainable approach to school change. Discourse and Communication for Sustainable Education, 8(2), 38-56.

Jurgena, I., Cēdere, D., \& Keviša, I. (2018). The Prospects of transdisciplinary approach to promote learners' cognitive interest in natural science for sustainable development. Journal of Teacher Education for Sustainability, 20(1), 5-19. DOI: 10.2478/jtes2018-0001

Kabadayi, A. (2016). A suggested in-service training model based on Turkish preschool teachers' conceptions for sustainable development. Journal of Teacher Education for Sustainability, 18(1), 5-15.

Kalaitzidis, D. (2012). Sustainable school indicators: approaching the vision through the sustainable school award. Journal of Teacher Education for Sustainability, 14(2), 168-180.

Kapenieks, J. (2016). Educational action research to achieve the essential competencies of the future. Journal of Teacher Education for Sustainability, 18(1), 95-110.

Kapenieks, J., \& Salīte, I. (2012). Action research for creating knowledge in an e-learning environment. Journal of Teacher Education for Sustainability, 14(2), 111-129.

Koopmans, M., \& Stamovlasis, D. (2016). Complex dynamical systems in education. Concepts, methods and applications. Heidelberg: Springer.

Kravale-Paulina, M., \& Oḷehnoviča, E. (2015). Human securitability: A participatory action research study involving novice teachers and youngsters. Journal of Teacher Education for Sustainability, 17(2), 91-107.

Kress, J. W., \& Stine J. K. (2017). Living in the Anthropocene: Earth in the Age of Humans. Washington: Smithsonian Institution Scholarly Press.

Levickaitè, R. (2010). Generations X, Y, Z: How Social Networks form the Concept of the World without Borders (The Case of Lithuania). Journal LIMES: Cultural Regionalistics, 3 (2). 
Lewin, R. (1999). Complexity: Life to the edge of chaos. 2nd edition. Chicago: The University of Chicago Press.

Miedema, S., \& Bertram-Troost, G. (2015). The challenges of global citizenship for worldview education. The perspective of social sustainability. Journal of Teacher Education for Sustainability, 17(2), 44-52.

Millett, D. (2015). Anthropocene: The age of man. North Charleston: A DBA of OnDemand Publishing LLC.

Mitchell, M. (2009). Complexity. A guided tour. Oxford: Oxford University Press.

Morin, E. (2008). On complexity. New York: Hamton Press.

Niiniluoto, I. (2002). Critical scientific realism. Oxford: Oxford University Press.

Norman, A. D. (2011). Living with complexity. London: The MIT Press.

Pace, P. (2010). Self-evaluation as a tool in developing environmental responsibility. Journal of Teacher Education for Sustainability, 12(1), 5-26.

Pētersons, E. (1931). Vispārīgā didaktika. Rīga: A. Gulbis.

Pipere, A., \& Salite, I. (2006). Educational action research in Teacher education: Fostering research skills. Journal Proceedings of Asia-Pacific Educational Research Association International Conference Educational Research, Policy and Practice in an Era of Globalization. 2830, 2006/11.

Pipere, A., Veisson, M., \& Salite, I. (2015). Developing research in teacher education for sustainability: UN DESD via the Journal of Teacher Education for Sustainability. Journal of Teacher Education for Sustainability, 17(2), 5-43.

Revonsuo, A. (2006). Consciousness as a Biological Phenomenon. Cambridge: The MIT Press.

Reyes, V. C. (2018). Educational research in the age of Anthropocene. Retrieved June 14, 2018 from https://books.google.lv/books?isbn=1522553177

Salite, I. (1998). An ecocentric paradigm: An important tool for teachers of environmental education. Australian Journal of Environmental Education, 14, 81-85, Cambridge: Cambridge University Press.

Salite, I. (2008). Educational action research for sustainability: Constructing a vision for the Future in teacher education. Journal of Teacher Education for Sustainability, $10,5-16$.

Salite, I. (2015). Searching for sustainability in teacher education and educational research: experiences from the Baltic and Black Sea Circle Consortium for educational research. Discourse and Communication for Sustainable Education, 6, 21-29.

Salìte, I., Drelinga, E., Iliško, Dz., Oḷehnoviča, E., \& Zarina, S. (2016). Sustainability from the transdisciplinary perspective: An action research strategy for continuing Education Program Development. Journal of Teacher Education for Sustainability, 18(2), 135-152.

Salīte, I., Gedžūne, G., \& Gedžūne, I. (2009). Educational action research for sustainability: seeking wisdom of insight in teacher education. Journal of Teacher Education for Sustainability, 11(2), 14-30.

Salumaa, T. (2007). Changes in organizational culture in schools and readiness of teachers for those changes. Journal of Teacher Education for Sustainability, 8, 5-13.

Savio, J.D. (2010). Beyond cultural boundaries - Towards reasoning our mental frameworks. UK: Academy Press.

Schlossberg, M. (2016). Teen Generation Z is being called 'millennials on steroids', and that could be terrifying for retailers. Business Insider UK, February 11, 2016. 
Retrieved January 10, 2018, from http://uk.businessinsider.com/millennials-vs-genz-2016-2

Soobik, M. (2014). Teaching Methods Influencing the Sustainability of the Teaching Process in Technology Education in General Education Schools. Journal of Teacher Education for Sustainability, 16(1), 89-101.

Students, J. (1998). Vispārīgā pedagogiija, 2. daļa. Rìga: RaKa.

Sustainable Development Goals (SDGs). (n.d.). Retrieved from https://sustainable development.un.org/?menu $=1300$

Tillmans, T., Holland, C., \& Filho, A. S. (2017). Design criteria for visual cues used in disruptive learning interventions within sustainability education. Discourse and Communication for Sustainable Education, 8(2), 5-16.

Tønnessen, M., Oma, K. A., \& Rattasepp, S. (2016). Thinking about animals in the age of the Anthropocene. London: Lexington Book.

Turner, A., (2015). Generation Z: Technology and social interest, The Journal of Individual Psychology, 71(2). Texas: The University of Texas Press.

UN. (1987). Our Common Future. Report of the World Commission on Environment and Development. Retrieved June 13, 2018 from: http:/www.exteriores.gob.es/ Portal/es/PoliticaExteriorCooperacion/Desarrollosostenible/Documents/Informe \% 20Brundtland\%20(En\%20ingl\%C3\%A9s).pdf

UN. (2011). Learning for the future: Competences in Education for Sustainable Development. Retrieved June 13, 2018 from file://C:/Users/Dzintra/Desktop/ECE_CEP_ AC13_2011_6\%20COMPETENCES\%20EN.pdf

Van den Bergh, J., \& Behrer, M. (2016). How cool brands stay hot: Branding to Generations $Y$ and $Z$. London: Kogan Page Publishers.

Waldrop, M. M. (1992). Complexity. The emerging science at the edge of order and chaos. New York: Simon \& Schuster paperbacks.

Wells, J. (2013). Routledge studies in ecological economics. Complexity and sustainability. Abingdon: Routledge.

Whitehead, A. N. (1929). The aims of education. New York: The Free Press.

Zunker, V. G. (2012). Eighth edition. Career counseling. A holistic approach. Andover: Brooks/Cole, Cengage Learning.

Žogla, I. (2001). Didaktikas teorētiskie pamati. Rīga: RaKa.

Вахтеров, В. П. (1913). Основы новой педагогики. Том 1. Москва: Изданіе (Типографія) Т-ва И. Д. Сытина. Retrieved June 5, 2018 from http://elib.gnpbu.ru/text/ vahterov_osnovy-novoy-pedagogiki_1913/fs,1/

Сапа, А. В. (2014). Поколение z - поколение эпохи фгос, инновационные проекты и программы в образовании. Издательство: Инновации и эксперимент в образовании (Москва), том 2, 24-30 стр. ISSN: 2306-8310.

Correspondence concerning this paper should be addressed to Dzintra Iliško, PhD. Daugavpils University, Parades street 1, Daugavpils, Latvia, LV-5401. Email: dzintra.ilisko@du.lv 